\title{
High-density thermoplastic vulcanizates based on LLDPE/NR for truck floor mats application
}

\author{
Dwi Wahini Nurhajati*, Umi Reza Lestari \\ Center for Leather, Rubber, and Plastics, Jl. Sokonandi No. 9, Yogyakarta 55166, Indonesia \\ * Corresponding author. Tel.: +62 274 512929, 563939; Fax: +62 274563655 \\ E-mail: dwiwahini@kemenperin.go.id, dwiwahini@gmail.com
}

Submitted: 28 August 2021

Revised: 10 September 2021

Accepted: 21 September 2021

\begin{abstract}
The use of thermoplastic vulcanizates (TPVs) that was obtained from a blend of thermoplastics and natural rubbers are considered suitable for the automotive application. To modify the performance of TPVs to high-density TPVs, a high-density filler such as bismuth oxide $\left(\mathrm{Bi}_{2} \mathrm{O}_{3}\right)$ was added. The focus of this study was on the development of high-density TPVs based on linear low-density polyethylene (LLDPE)/natural rubber (NR) blend with different proportions of $\mathrm{Bi}_{2} \mathrm{O}_{3}$ filler that meets with requirements for truck floor mats material. The high-density TPVs were prepared by melt blending in a kneader. Bismuth oxide filler loading was varied by 50, 150, 200, $250 \mathrm{phr}$, and 300 phr. An increase in the weight load of bismuth oxide in TPVs increases density, hardness, and volume loss but reduces the tensile properties, tear strength, and burning rate of high-density TPVs. The test results showed that the TPVs containing $250 \mathrm{phr} \mathrm{Bi}_{2} \mathrm{O}_{3}$ was a promising candidate for use as a truck floor base.
\end{abstract}

Keywords: high-density thermoplastic vulcanizates, $\mathrm{Bi}_{2} \mathrm{O}_{3}$, linear low-density polyethylene, natural rubber, truck floor mats material.

\section{INTRODUCTION}

Thermoplastic vulcanizates (TPVs) are a specific group of thermoplastic elastomers (TPE) prepared by dynamic vulcanization of a thermoplastic and an elastomer, where the crosslinking of the elastomeric phase occurs during melt mixing with molten thermoplastics (Bhattacharya et al., 2020). TPVs can be used in the manufacture of a variety of products and may be useful for making automotive interiors, such as instrument panels, floor consoles, and door panels.

High-density thermoplastic compounds are material have high specific gravity between 2 and 11 by adding high-density mineral filler or metal powder to the plastic matrix (Scheepens, 2016). Many high-density mineral fillers or metal powder are used to make high-density thermoplastic compounds like zinc, brass, silver, bismuth, molybdenum, solid tungsten steel, tungsten bismuth, and copper. Thermoplastic elastomer (TPE) compound with high specific gravity has a special market, such as for radiation shielding, projectiles, sporting goods, military, automotive, packaging and noise attenuation. One of the applications of high-specific gravity material, that may be used in automotive, is for sound-proof floor mat.

Bismuth oxide is one of the high-density metal oxides with a density of $8.9 \mathrm{~g} / \mathrm{cc}$ which is less than that of lead and greater than that of barite and steel and is nontoxic (Ambika et al., 2017). Several researchers have studied bismuth oxide filled materials explored in various applications, such as for radiation shields (Abdalsalam et al., 2020; Pavlenko et al., 2019; Sheela et al., 2019), biomedical applications (Jagdale et al., 2021; Arnold et al., 2021), electronic application (Elabbasy et al., 2021; Singh et al., 2019). However, there were no reports for automotive application. This paper aimed to develop highdensity thermoplastic vulcanizates based on linear low-density polyethylene (LLDPE)/natural rubber (NR) blend with different proportions of bismuth oxide $\left(\mathrm{Bi}_{2} \mathrm{O}_{3}\right)$ filler that meets with requirements for truck floor mats material. 


\section{MATERIALS AND METHODS Materials}

Linear low-density polyethylene (LLDPE) granules (extrusion grade, a density of $0.921 \mathrm{~g} /$ $\mathrm{cm}^{3}$, melt index of $1 \mathrm{~g} / 10 \mathrm{~min}$ at $190{ }^{\circ} \mathrm{C} / 2.16 \mathrm{~kg}$ ) were purchased from a local supplier. Natural rubber (NR) grade SIR 20 was purchased from a local estate. The rubber ingredients used to make the rubber compounds in this research were the standard ones for the rubber industry consisted of cure activators $\mathrm{ZnO}$ and stearic acid), N-Cyclohexylbenzothiazole-2-sulfenamide (CBS) as an accelerator, a filler (carbon black N330), a vulcanizing agent (sulfur), a processing oil (paraffinic oil), 2,2,4-Trimethyl-1,2Dihydroquinoline (TMQ), N-(1,3-dimethylbutyl)$\mathrm{N}$ '-phenyl-p-phenylenediamine (6PPD), and $\mathrm{N}$-isopropyl-N'-phenyl-p-phenylenediamine (IPPD) as the antioxidants, prevulcanization inhibitor (PVI). The rubber ingredients were purchased from a local supplier. Maleic anhydridegraft-polyethylene (MA-g-PE) as a compatibilizer and the commercial antioxidant (Irganox 1010) were purchased from Sigma Aldrich supplier. The high-density filler used in this research was a bismuth oxide $\left(\mathrm{Bi}_{2} \mathrm{O}_{3}\right)$ with a density of $8.9 \mathrm{~g} / \mathrm{cm}^{3}$.

\section{Methods \\ High-density TPVs preparation}

For the first step, the natural rubber was compounded with rubber ingredients by a tworoll mill for around $15 \mathrm{~min}$. In this research, the composition of rubber compound consists of $100 \mathrm{phr}$ of natural rubber, $5 \mathrm{phr}$ of $\mathrm{ZnO}, 2 \mathrm{phr}$ of stearic acid, $1 \mathrm{phr}$ of TMQ, $1 \mathrm{phr}$ of CBS, $1.5 \mathrm{phr}$ of sulfur, $5 \mathrm{phr}$ of paraffinic oil, $1 \mathrm{phr}$ of $6 \mathrm{PPD}, 1$ phr of IPPD, and $0.1 \mathrm{phr}$ of PVI.

In the second step, the rubber compounds were blended with LLDPE, MA-g-PE, Irganox 1010, and $\mathrm{Bi}_{2} \mathrm{O}_{3}$ in a kneader at $130{ }^{\circ} \mathrm{C}$, for 15 minutes, to make high-density TPVs. The composition of high-density TPVs consisted of 75 phr of LLDPE, $25 \mathrm{phr}$ of a rubber compound, $5 \mathrm{phr}$ of MA-g-PE, $0.1 \mathrm{phr}$ of Irganox 1010, and a varied amount of $\mathrm{Bi}_{2} \mathrm{O}_{3}$ filler. $\mathrm{Bi}_{2} \mathrm{O}_{3}$ filler loading was varied by 50 , $150,200,250$, and $300 \mathrm{phr}$.

\section{Characterization}

The tensile strength, elongation at break, and tear strength of TPVs were done at room temperature $\left(23 \pm 2{ }^{\circ} \mathrm{C}\right)$ with a Universal Testing Machine (UTM-Tinius Olsen H25K), before and after aging. The tensile strength and elongation at break were tested according to ISO (2017a) using a dumbbell-type 2 specimen, an angle-type specimen used for tear strength testing according to ISO (2015). The Shore A hardness was measured according to ISO (2018a) using a Shore A durometer (Toyoseiki). Density was carried out using an electron densimeter (EW-200SG, Mirage) following ISO (2018b) Method A. All TPVs were also assessed for mechanical properties changes after thermal aging. The test was carried out by putting all the samples in an oven at $70{ }^{\circ} \mathrm{C}$ for 7 days, after which tensile strength, elongation at break, tear strength, and hardness (Shore A) tests were performed, following the same procedures and standard testing used on the samples before thermal aging.

The abrasion resistance test was done with a rotary drum abrasion tester (Bareiss) according to ISO (2017b) using the cylindrical shape specimens with a diameter of $16 \pm 0.2 \mathrm{~mm}$ and a height of $6 \mathrm{~mm}$. The abrasion resistance test result was expressed as a relative volume loss compared to an abrasive sheet calibrated using a standard reference compound.

The flammability test was determined following ASTM (2018). TPVs samples, with dimensions of specimen size were $125 \pm 0.2 \mathrm{~mm}$ long, $13 \pm 0.2 \mathrm{~mm}$ wide, and thickness of $2 \pm 0.5$ $\mathrm{mm}$, were tested at a horizontal position by using a flame from a bunsen burner. During the test, time to ignition (TTI), and the time required to perform combustion of TPVs specimens as far as $\mathrm{L}(75 \mathrm{~mm})$ were recorded. The burning rate was calculated from equation (1).

Burning rate $(\mathrm{mm} / \mathrm{min})=.\frac{60 \mathrm{~L}}{\mathrm{t}}$

where:

$\mathrm{L}=$ the burned length, in millimetres $=75 \mathrm{~mm}$ $\mathrm{t}=$ the burning time (sec.)

\section{RESULTS AND DISCUSSION \\ Density Before and After Aging}

High-density TPVs is a material that has a density exceeding about $2.0 \mathrm{~g} / \mathrm{cm}^{3}$. The density of TPVs samples before and after aging are shown in Figure 1. The $\mathrm{Bi}_{2} \mathrm{O}_{3}$ filler had higher density than the other constituents of the formulation and the density increased by raising the $\mathrm{Bi}_{2} \mathrm{O}_{3}$ content in the composites, as observed in Figure 1. This 


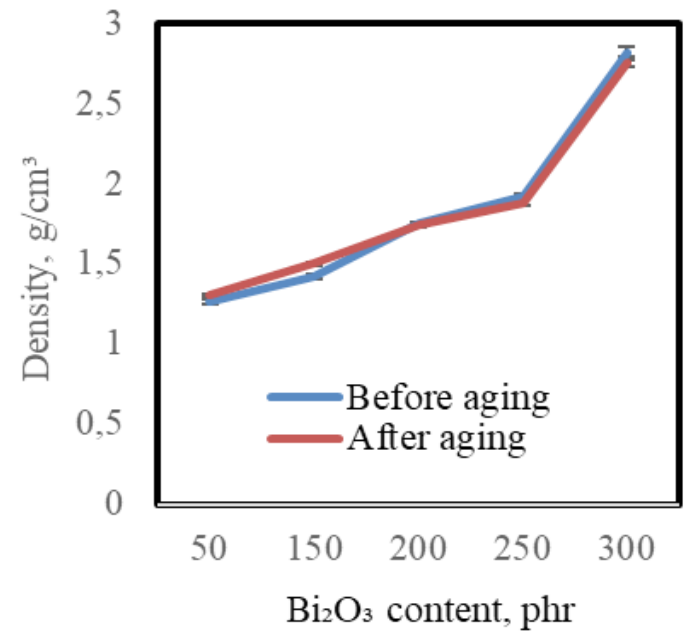

Figure 1. The density of TPVs at various $\mathrm{Bi}_{2} \mathrm{O}_{3}$ content, before and after thermal aging.

was due to the much larger densities of the $\mathrm{Bi}_{2} \mathrm{O}_{3}$ powders $\left(8.9 \mathrm{~g} / \mathrm{cm}^{3}\right)$ compared to the density of NR and LLDPE. A similar trend, regarding highdensity fillers, leading to an increase in composite density was reported by Poltabtim et al. (2018), Toyen et al. (2018), Al-Mattarneh and Dahim (2019), and Pavlenko et al. (2019).

Figure 1 shows the density of TPVs containing $50 \mathrm{phr}$ of $\mathrm{Bi}_{2} \mathrm{O}_{3}$ filler is $1.26 \pm 0.016 \mathrm{~g} / \mathrm{cm}^{3}$. When $300 \mathrm{phr}$ of $\mathrm{Bi}_{2} \mathrm{O}_{3}$ filler was added to the TPVS, the density of TPVs increased to $2.82 \pm 0.032 \mathrm{~g} / \mathrm{cm}^{3}$ (an increase of $123.81 \%$ ). The density of TPVs before and after accelerated thermal aging at the temperature of $70{ }^{\circ} \mathrm{C}$ during 72 hours have range $1.26 \pm 0.013$ to $2.82 \pm 0.0132 \mathrm{~g} / \mathrm{cm}^{3}$ and $1.3 \pm 0.012$ to $2.75 \pm 0.022 \mathrm{~g} / \mathrm{cm}^{3}$, respectively. Accelerated thermal aging did not affect the density of TPVs, because the change in the average maximum density was $5.60 \%$ as indicated by the TPVs containing $\mathrm{Bi}_{2} \mathrm{O}_{3}$ filler up to $150 \mathrm{phr}$, while the change in the average density of TPVs composites containing $\mathrm{Bi}_{2} \mathrm{O}_{3}$ filler was above $150 \mathrm{phr}$, was not very significant, namely $2.48 \%$. The density required for TPE-based trucks floor mats by one of the automotive companies is $2 \pm 0.2 \mathrm{~g} / \mathrm{cm}^{3}$, and TPVs composite containing $250 \mathrm{phr}$ of $\mathrm{Bi}_{2} \mathrm{O}_{3}$ filler can meet these requirements. However, the density of one of the commercial TPEs $\left(1.75 \mathrm{~g} / \mathrm{cm}^{3}\right)$ for truck floor mats did not yet meet this requirement.

\section{Hardness Before and After Aging}

The hardness before and after aging of the obtained TPVs are presented in Figure 2. The results were depended on the content of $\mathrm{Bi}_{2} \mathrm{O}_{3}$.

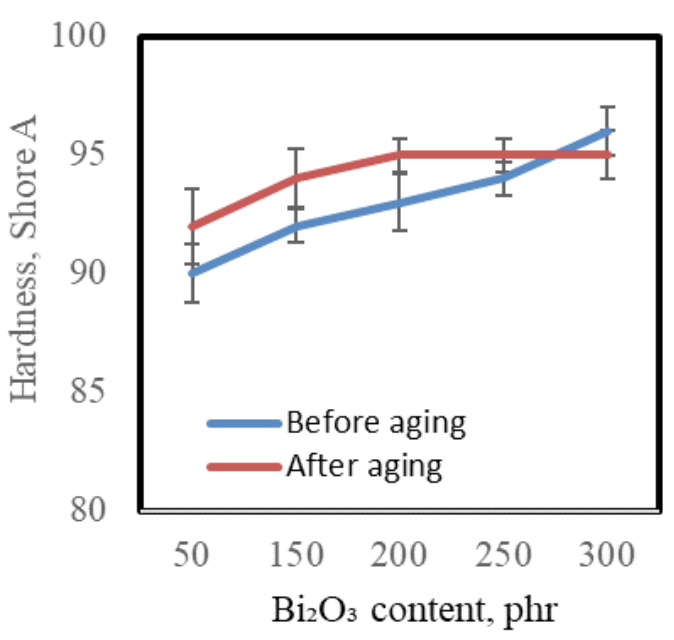

Figure 2. The hardness of TPVs at various $\mathrm{Bi}_{2} \mathrm{O}_{3}$ content.

The increase of $\mathrm{Bi}_{2} \mathrm{O}_{3}$ filler loading significantly increased hardness due to the high rigidity of metal oxide powder in TPVs composite. A similar trend regarding high-density fillers loading resulted in the rise in hardness was reported by Mysiukiewicz et al. (2020) and El-Fiki et al. (2015). The hardness of the TPVs samples before aging was in the range of $90 \pm 1.225-96 \pm 1$ Shore A. The hardness of thermal aged TPVs containing $\mathrm{Bi}_{2} \mathrm{O}_{3}$ fillers up to $250 \mathrm{phr}$ was higher than that of the unaged. It can be indicated that the post vulcanization reaction of natural rubber compounds during the aging process increased hardness. Meanwhile, the hardness of thermally aged TPVs containing $300 \mathrm{phr}$ of $\mathrm{Bi}_{2} \mathrm{O}_{3}$ filler was lower than unaged (decreased 2.48\%). According to Ali and Pajarito (2018), the decrease in the hardness of the rubber composite due to thermal aging was caused by the degradation of the natural rubber main chain. The hardness range of the TPVs samples after aging was $92 \pm 1.581-95 \pm 1$ Shore A.

The hardness required for TPE-based trucks floor mats by one of the automotive companies is $90 \pm 5$ Shore $\mathrm{A}$, and TPVs containing $\mathrm{Bi}_{2} \mathrm{O}_{3}$ filler up to $250 \mathrm{phr}$ can meet these requirements. The hardness of one of the commercial TPEs (85 Shore A) for the same application meet this requirement.

\section{Tensile Properties Before and After aging}

The tensile properties of before and after aging TPVs as a function of $\mathrm{Bi}_{2} \mathrm{O}_{3}$ filler loading are displayed in Figure 3. Figure 3 shows that the tensile strength and elongation at break of the TPVs decreased with the increase of $\mathrm{Bi}_{2} \mathrm{O}_{3}$ 


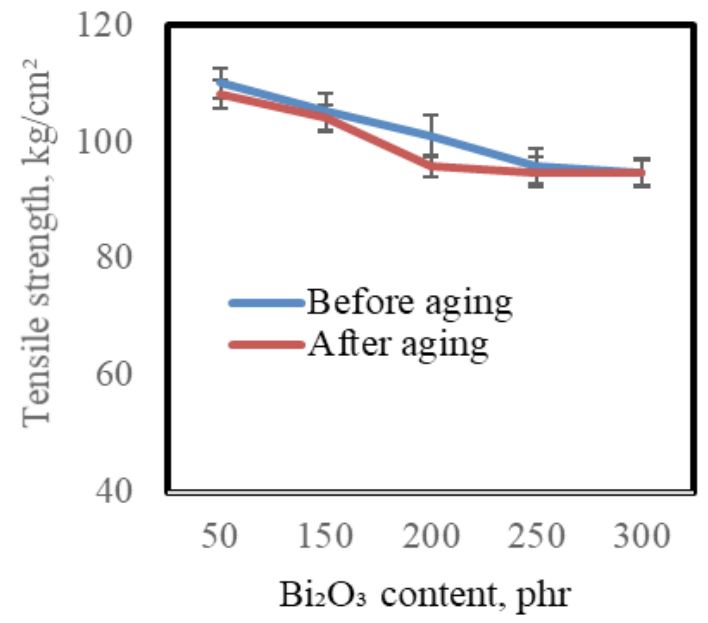

(a)

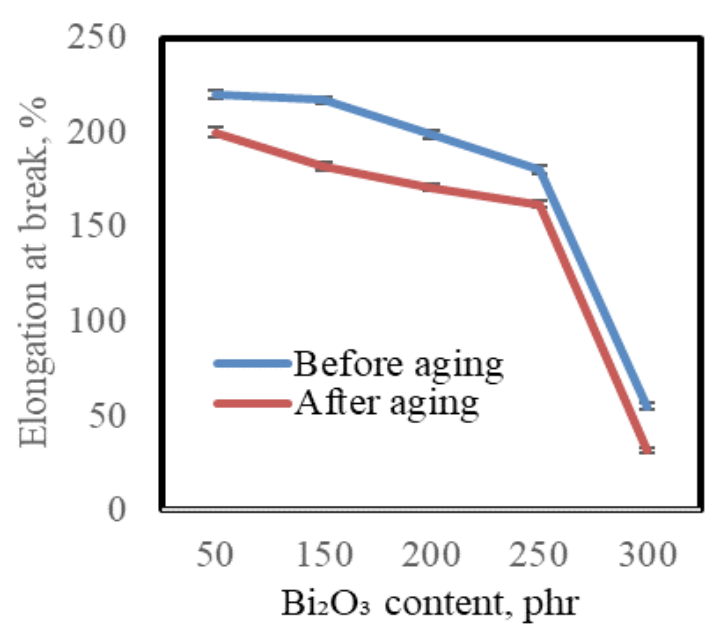

(b)

Figure 3. Effect of $\mathrm{Bi}_{2} \mathrm{O}_{3}$ content on tensile strength (a) and elongation at break (b) for TPVs before and after thermal aging.

filler loading. The same trend was observed in tear strength values (Figure 4). The addition of high amounts of $\mathrm{Bi}_{2} \mathrm{O}_{3}$ filler particles can cause agglomeration of filler due to the interaction between fillers. The decrease in tensile strength may be due to the agglomeration of metal oxide particles which resulted in the weakening of the bond between the metal oxide particles and TPVs as a matrix. The decrease in elongation at break might be due to a decrease in ductility associated with the incorporation of an excess of metal oxide fillers into the polymer matrix. Such decreasing tensile strength and elongation at break with high load filler was also reported by Datta et al. (2016), Yuhaida et al. (2016), Onuoha et al. (2017), Poltabtim et al. (2018), and Lopattananon et al. (2019).

The highest tensile strength $(110 \pm 2.549 \mathrm{~kg} /$ $\left.\mathrm{cm}^{2}\right)$ and elongation at break $(220 \pm 1.871 \%)$ value were achieved by TPVs containing the lowest $\mathrm{Bi}_{2} \mathrm{O}_{3}$ filler (50 phr). On the other hand, the highest $\mathrm{Bi}_{2} \mathrm{O}_{3}$ filler content $(300 \mathrm{phr})$ resulted in the lowest tensile strength $\left(94.8 \pm 2.280 \mathrm{~kg} / \mathrm{cm}^{2}\right)$ and elongation at break (55.2 $\pm 2.168 \%)$. An increase in $\mathrm{Bi}_{2} \mathrm{O}_{3}$ filler from $50 \mathrm{phr}$ to $300 \mathrm{phr}$ caused a decrease in tensile strength and elongation at break of $13.82 \%$ and $74.91 \%$, respectively.

After accelerated thermal aging, the tensile strength and elongation at break of TPVs composites containing $\mathrm{Bi}_{2} \mathrm{O}_{3}$ filler tended to decrease. According to Park (2013), the decrease in tensile properties after thermal aging could be related to the increase in brittleness of specimens driven by chain scission and degradation during the aging process. Elongation at break became lower after thermal aging due to the high elasticity of composites.

The test results for the tensile strength and elongation at break of commercial TPE for truck floor mats before aging were $23.7 \mathrm{~kg} / \mathrm{cm}^{2}$ and $23.3 \%$, respectively, and after aging were $25.3 \mathrm{~kg} /$ $\mathrm{cm}^{2}$ and $10.6 \%$, respectively. These values were lower than the tensile strength and elongation at break values of all TPVs composites produced in this study.

\section{Tear Strength Before and After Aging}

Tear strength before and after aging of the obtained TPVs composites are presented in Figure 4. The tear strength of all samples were decreased with the increase in $\mathrm{Bi}_{2} \mathrm{O}_{3}$ loading. According to Wickramaarachchi et al. (2020), poor interaction between filler and matrix decreased the tear strength of composites.

The highest tear strength value before aging $(86 \pm 1.581 \mathrm{~N} / \mathrm{mm})$ was shown by TPVs containing $\mathrm{Bi}_{2} \mathrm{O}_{3}$ filler 50 phr. The addition of $\mathrm{Bi}_{2} \mathrm{O}_{3}$ of 250 $\mathrm{phr}$ and $300 \mathrm{phr}$ gave a decrease in the tear strength of $8.37 \%$ and $31.16 \%$, respectively, compared to TPVs composite containing $50 \mathrm{phr} \mathrm{Bi}_{2} \mathrm{O}_{3}$ filler. The highest tear strength value after aging $(85.6 \pm 1.516$ $\mathrm{N} / \mathrm{mm}$ ) was obtained for TPVs containing $\mathrm{Bi}_{2} \mathrm{O}_{3}$ filler at $50 \mathrm{phr}$. The tear strength of the aged TPVs was lower than that of the non-aging. This might be attributed to the increase in brittleness of TPVs driven by chain scission and degradation during 


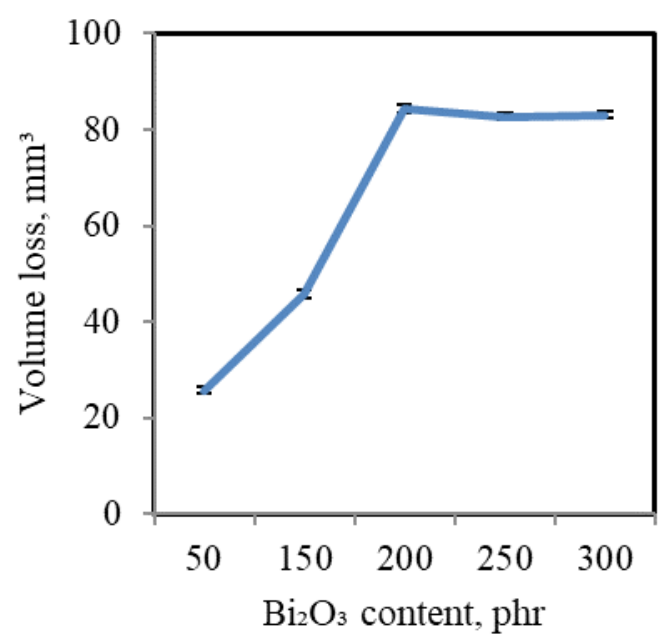

Figure 4. Tear strength of TPVs at various $\mathrm{Bi}_{2} \mathrm{O}_{3}$ content, before and after thermal aging.

the aging process. Decreasing in tear strength after thermal aging was also reported by Li et al. (2015). The tear strength of one of the commercial TPE $(27.3 \mathrm{~N} / \mathrm{mm})$ for truck floor mats is lower than the tear strength of all TPVs composites that resulted in this study.

\section{Abrasion Resistance}

The abrasion resistance of the TPVs expressed as volume loss is shown in Figure 5. An increase in volume loss means a decrease in abrasion resistance. The addition of $\mathrm{Bi}_{2} \mathrm{O}_{3}$ filler to TPVs decreases the abrasion resistance. The lowest volume lost value $\left(25.8 \pm 0.837 \mathrm{~mm}^{3}\right)$ was demonstrated by TPV containing $50 \mathrm{phr}$ of $\mathrm{Bi}_{2} \mathrm{O}_{3}$ filler. The highest volume lost value $(84.4 \pm 0.894$ $\mathrm{mm}^{3}$ ) was observed by TPVs containing $\mathrm{Bi}_{2} \mathrm{O}_{3}$ filler at $200 \mathrm{phr}$. There was an $84.28 \%$ increase compared to volume loss of the TPVs containing $150 \mathrm{phr} \mathrm{Bi}{ }_{2} \mathrm{O}_{3}$ filler $\left(45.8 \pm 0.84 \mathrm{~mm}^{3}\right)$. The increase in volume loss indicates a decrease in abrasion resistance. According to Mrówka et al. (2021), the decrease in abrasion resistance for higher filler content was due to the agglomeration of the filler. During abrasion, the filler agglomerate might detach from the sample, thus increasing

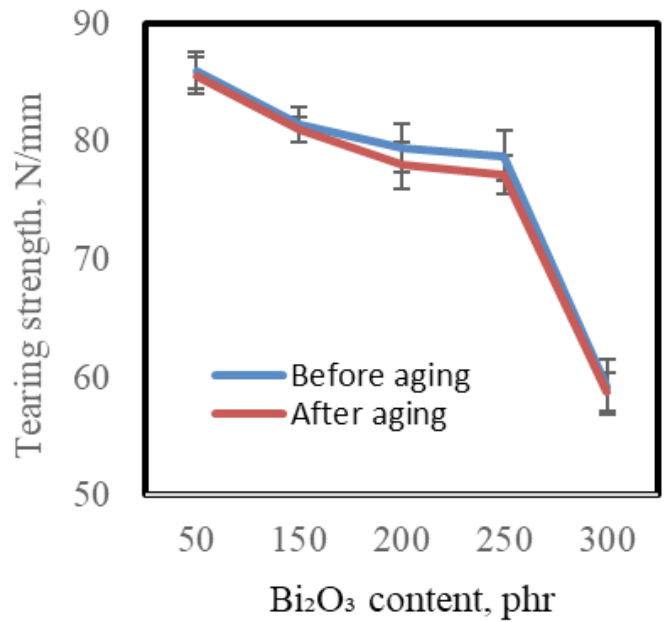

Figure 5. Volume loss of TPVs at various $\mathrm{Bi}_{2} \mathrm{O}_{3}$ content.

the volume loss. Volume loss of TPVs containing $\mathrm{Bi}_{2} \mathrm{O}_{3}$ filler at 50,150, and $300 \mathrm{phr}$ were lower than one of commercial TPE $\left(76.09 \mathrm{~mm}^{3}\right)$ for truck floor mats. However, TPVs containing 200 phr and $250 \mathrm{phr} \mathrm{Bi}_{2} \mathrm{O}_{3}$ filler were $10.92 \%$ and $8.81 \%$ higher, respectively, than volume loss of one of commercial TPE.

\section{Flammability}

Burning test is important for assessing the flammability properties of truck floor mats. According to Borowicz et al. (2019), time-toignition is one of the most important flameretardancy parameters, because it determines how fast the material combustion will occur when exposed to a heat source. Additionally, according to ASTM (2018), it is necessary to record the time required to burn the TPVs specimen as far as $\mathrm{L}(75 \mathrm{~mm})$ to calculate the burning rate (BR). In this research, the addition of metal oxide filler was expected to increase the composite burn resistance. The effect of $\mathrm{Bi}_{2} \mathrm{O}_{3}$ filler loading on the flammability properties of high-density TPVs are listed in Table 1.

Table 1 shows that increasing the $\mathrm{Bi}_{2} \mathrm{O}_{3}$ content gradually increases the time to ignition

Table 1. Burning rate for high-density TPVs.

\begin{tabular}{cccc}
\hline $\mathrm{Bi}_{2} \mathrm{O}_{3}$ filler content $(\mathrm{phr})$ & time to ignition $(\mathrm{sec})$ & Time to $75 \mathrm{~mm}(\mathrm{sec})$ & Burning rate $(\mathrm{mm} / \mathrm{min})$ \\
\hline 50 & 52 & 100 & 45.00 \\
150 & 60 & 113 & 40.00 \\
200 & 66 & 120 & 37.50 \\
250 & 70 & 150 & 30.00 \\
300 & 128 & 234 & 19.23 \\
\hline
\end{tabular}


(TTI). The longer the TTI value, the probability of fire is lower (Borowicz et al., 2019). As shown in Table 1, the ignition time of composite containing $50 \mathrm{phr} \mathrm{Bi}_{2} \mathrm{O}_{3}$ filler is 52 seconds, and an increase in $\mathrm{Bi}_{2} \mathrm{O}_{3}$ filler from $50 \mathrm{phr}$ to $300 \mathrm{phr}$ caused an increase in TTI of $148.15 \%$. According to Jagdale et al. (2018), $\mathrm{Bi}_{2} \mathrm{O}_{3}$ is the filler that has high impact on the ignition time of the composite, and TTI of $\mathrm{Bi}_{2} \mathrm{O}_{3}(1-3 \%)$ reinforced composites was increased by $15-20$ seconds. This may be due to the high thermal stability of the $\mathrm{Bi}_{2} \mathrm{O}_{3}$ filler. From Table 1, it is clear that at $\mathrm{Bi}_{2} \mathrm{O}_{3}$ filler loading of $300 \mathrm{phr}$ observed the lowest value of burning rate (19.23 $\mathrm{mm} / \mathrm{min}$ ), which indicated the sample burned slowly. From the results, it is clear that the addition of $\mathrm{Bi}_{2} \mathrm{O}_{3}$ filler in the TPVs results in decreasing the rate of burning, and hence improves flammability resistance. Test results from one of the commercial TPE showed the burning rate was $66.67 \mathrm{~mm} / \mathrm{min}$. This value was higher than the burning rate from and all of TPVS composite resulted in this study.

\section{CONCLUSIONS}

High-density TPVs were prepared by adding different weight loads $(50,150,200,250,300$ phr) of bismuth oxide $\left(\mathrm{Bi}_{2} \mathrm{O}_{3}\right)$ filler in linear lowdensity polyethylene (LLDPE)/natural rubber (NR) matrix by melt blending in a kneader. The effect of the amount of $\mathrm{Bi}_{2} \mathrm{O}_{3}$ filler on the physical and mechanical properties in the 75/25 LLDPE/ NR blend was investigated. An increase in the weight load of bismuth oxide in TPVs increases density, hardness, and volume loss but reduces the tensile properties, tear strength, and burning rate of high-density TPVs. The results show that high-density thermoplastic vulcanizate containing $250 \mathrm{phr} \mathrm{Bi}_{2} \mathrm{O}_{3}$ is a promising candidate for use as a truck floor base. The properties of this high-density thermoplastic vulcanizate before aging were density $1.92 \pm 0.01 \mathrm{~g} / \mathrm{cm}^{3}$, hardness $94 \pm 0.707$ Shore A, tensile strength $95.8 \pm 2.95 \mathrm{~kg} / \mathrm{cm}^{2}$, elongation at break $180 \pm 2.345 \%$, tear strength $78.8 \pm 2.168 \mathrm{~N} /$ $\mathrm{mm}$, volume loss $82.8 \pm 0.837 \mathrm{~mm}^{3}$, burning rate $30 \mathrm{~mm} / \mathrm{min}$. Properties after aging were density $1.88 \pm 0.021 \mathrm{~g} / \mathrm{cm}^{3}$, hardness $95 \pm 0.707$ Shore A, tensile strength $94.8 \pm 2.683 \mathrm{~kg} / \mathrm{cm}^{2}$, elongation at break $162 \pm 1.871 \%$, and tear strength $77.2 \pm 1.643$ $\mathrm{N} / \mathrm{mm}$.

\section{ACKNOWLEDGEMENTS}

This research was funded by the Indonesian government under DIPA 2019. The authors are grateful to the Head of Center for Leather, Rubber, and Plastics, and research team for the support during the research that has been conducted. We also thank Metal Industries Development Center (MIDC) for providing Haake Rheomix machine facility for composite preparation.

\section{REFERENCES}

Abdalsalam, A. H., Şakar, E., Kaky, K. M., Mhareb, M. H. A., Şakar, B. C., Sayyed, M. I., \& Gürol, A. (2020). Investigation of gamma ray attenuation features of bismuth oxide nano powder reinforced high-density polyethylene matrix composites. Radiation Physics and Chemistry, 168, 108537. $\quad$ https://doi.org/10.1016/j. radphyschem.2019.108537

Ali, M. R., R., \& Pajarito, B. B. (2018). Effect of thermal aging on hardness and tensile fracture of natural rubber composites based on silica and modified/raw bentonite filler system. Solid State Science and Technology, 26(1), 1-7.

Al-Mattarneh, H., \& Dahim, M. (2019). Physical and mechanical properties of microwave absorber material containing micro and nano barium ferrite. Advanced Materials Letters, 10(4), 259262. https://doi.org/10.5185/amlett.2019.2226

Ambika, M. R., Nagaiah, N., \& Suman, S. K. (2017). Role of bismuth oxide as a reinforcer on gamma shielding ability of unsaturated polyester based polymer composites. Journal of Applied Polymer Science, 134(13). $\quad$ https://doi.org/10.1002/ APP.44657

Arnold, J., Sarkar, K., \& Smith, D. (2021). 3D printed bismuth oxide-polylactic acid composites for radio-mimetic computed tomography spine phantoms. Journal of Biomedical Materials Research Part B: Applied Biomaterials, 109(6), 789-796. https://doi.org/10.1002/jbm.b.34744

ASTM (American Standard of Testing Material). (2018). ASTM D635-18, Standard test method for rate of burning and/or extent and time of burning of plastics in a horizontal position. West Conshohocken, PA, ASTM International. https:// doi.org/10.1520/D0635-18

Bhattacharya, A. B., Chatterjee, T., \& Naskar, K. (2020). Automotive applications of thermoplastic vulcanizates. Journal of Applied Polymer Science, 137(27), 49181. https://doi.org/10.1002/ app.49181

Borowicz, M., Paciorek-Sadowska, J., Lubczak, J., \& Czupryński, B. (2019). Biodegradable, flameretardant, and bio-based rigid polyurethane/ polyisocyanurate foams for thermal insulation application. Polymers, 11(11), 1816. https://doi. org/10.3390/polym 11111816

Datta, J., Kosiorek, P., \& Włoch, M. (2016). Effect of high loading of titanium dioxide particles on the 
morphology, mechanical and thermo-mechanical properties of the natural rubber-based composites. Iran Polymer Journal, 25, 1021-1035. https:// doi.org/10.1007/s13726-016-0488-7

Elabbasy, M. T., Abd El-Kader, M. F. H., Ismail, A. M., \& Menazea, A. A. (2021). Regulating the function of bismuth (III) oxide nanoparticles scattered in Chitosan/Poly (Vinyl Pyrrolidone) by laser ablation on electrical conductivity characterization and antimicrobial activity. Journal of Materials Research and Technology, 10, 1348-1354. $\quad$ https://doi.org/10.1016/j. jmrt.2020.12.109

El-Fiki, S., El Kameesy, S. U., El Nashar, D. E., Abou-Leila, M. A., El-Mansy, M. K., \& Ahmed, M. (2015). Influence of bismuth contents on mechanical and gamma ray attenuation properties of silicone rubber composite. International Journal of Advanced Research, 3(6), 10351039.

ISO (International Organization for Standardization) (2015). ISO 34-1:2015(en): Rubber, vulcanized or thermoplastic - Determination of tear strength - Part 1: Trouser, angle and crescent test pieces. Geneva, Switzerland, ISO.

ISO (International Organization for Standardization). (2017a). ISO 37:2017(en): Rubber vulcanized or thermoplastic - Determination of tensile stressstrain properties. Geneva, Switzerland, ISO.

ISO (International Organization for Standardization). (2017b). ISO 4649:2017(en): Rubber, vulcanized or thermoplastic - Determination of abrasion resistance using a rotating cylindrical drum device. Geneva, Switzerland, ISO.

ISO (International Organization for Standardization). (2018a). ISO 48-4:2018(en): Rubber vulcanized or thermoplastic - Determination of hardness - Part 4: Indentation hardness by durometer method (Shore hardness). Geneva, Switzerland, ISO.

ISO (International Organization for Standardization). (2018b). ISO 2781:2018(en): Rubber, vulcanized or thermoplastic - Determination of density (Method A). Geneva, Switzerland, ISO.

Jagdale, P., Salimpour, S., Islam, M. H., Cuttica, F., Hernandez, F. C. R., Tagliaferro1, A., \& Frache, A. (2018). Flame retardant effect of nano fillers on polydimethylsiloxane composites. Journal of Nanoscience and Nanotechnology, 18(2), 14681473. https://doi.org/10.1166/jnn.2018.15251

Jagdale, P., Serino, G., Oza, G., Audenino, A. L., Bignardi, C., Tagliaferro, A., \& Alvarez-Gayosso, C. (2021). Physical characterization of bismuth oxide nanoparticle based ceramic composite for future biomedical application. Materials, 14(7), 1626. https://doi.org/10.3390/ma14071626

Li, Y., Liu, X., Hu, X., \& Luo, W. (2015). Changes in tensile and tearing fracture properties of carbonblack filled rubber vulcanizates by thermal aging. Polymers for Advanced Technologies, 26(11), 1331-1335. https://doi.org/10.1002/pat.3683

Lopattananon, N., Walong, A., Kaesaman, A., \& Sakai. T. (2019). Mechanical, thermal and fire retardant characteristics of NR/PP/ATH thermoplastic vulcanizates. Walailak Journal of Science and Technology, 16(10), 723-737. https://doi. org/10.48048/wjst.2019.4436

Mrówka, M., Woźniak, S., Prężyna, S., \& Sławski, S. (2021). The influence of zinc waste filler on the tribological and mechanical properties of silicone-based composites. Polymers, 13(4), 585. https://doi.org/10.3390/polym13040585

Mysiukiewicz, O., Kosmela, P., Barczewski, M., \& Hejna, A. (2020). Mechanical, thermal and rheological properties of polyethylene-based composites filled with micrometric aluminum powder. Materials, 13(5), 1242. https://doi. org/10.3390/ma13051242

Onuoha, C., Onyemaobi, O. O., Anyakwo, C. N., \& Onuegbu, G. C. (2017). Effect of filler loading and particle size on the mechanical properties of periwinkle shell-filled recycled polypropylene composites. American Journal of Engineering Research, 6(4), 72-79.

Park, E. (2013). Effects of thermal and solvent aging on breakdown voltage of TPE, PBT/PET alloy, and PBT insulated low voltage electric wire. Journal of Polymers, 2013, 1-11, 493731. https://doi. org/10.1155/2013/493731

Pavlenko, V. I., Cherkashina, N. I., \& Yastrebinsky, R. N. (2019). Synthesis and radiation shielding properties of polyimide $/ \mathrm{Bi}_{2} \mathrm{O}_{3}$ composites. Heliyon, 5(5), E01703. https://doi.org/10.1016/j. heliyon.2019.e01703

Poltabtim, W., Wimolmala, E., \& Saenboonruang, K. (2018). Properties of lead-free gamma-ray shielding materials from metal oxide/EPDM rubber composites. Radiation Physics and Chemistry, 153, 1-9. https://doi.org/10.1016/j. radphyschem.2018.08.036

Scheepens, J. P. (2016). How to select and process high-density thermoplastic materials. Plastic Technology Online Magazine, March.

Sheela, M., Kamat, V. A., Kiran, K. U., \& Eshwarappa, K. M. (2019). Preparation and characterization of bismuth-filled high-density polyethylene composites for gamma-ray shielding. Radiation Protection and Environment, 42(4), 180-186. https://doi.org/10.4103/rpe.RPE_29_19

Singh, S., Sahoo, R. K., Shinde, N. M., Yun, J. M., Mane, R. S., \& Kim, K. H. (2019). Synthesis of $\mathrm{Bi}_{2} \mathrm{O}_{3}-\mathrm{MnO}_{2}$ nanocomposite electrode for wide-potential window high performance supercapacitor. Energies, 12(17), 3320. https:// 
doi.org/10.3390/en12173320

Toyen, D., Rittirong, A., Poltabtim, W., \& Saenboonruang, K. (2018). Flexible, lead-free, gamma-shielding materials based on natural rubber/metal oxide composites. Iranian Polymer Journal, 27, 33-41. https://doi.org/10.1007/ s13726-017-0584-3

Wickramaarachchi, W. V. W. H., Walpalage, S., \& Egodage, S. M. (2020). Effect of particulate fillers on natural rubber/high-density polyethylene blends for roofing application. Polymers and Polymer Composite, 29(6), 763-769. https://doi. org/10.1177/0967391120934615

Yuhaida, I., Salmah, H., Hanafi, I. \& Firuz, Z. (2016). The effect of acrylic acid on tensile and morphology properties of wollastonite filled high density polyethylene/natural rubber composites. Procedia Chemistry, 19, 401-405. https://doi. org/10.1016/j.proche.2016.03.030 